\title{
IMPLEMENTASI HAK ATAS AHLI WARIS ANAK KANDUNG NON MUSLIM DALAM PERSPEKTIF HUKUM ISLAM YANG BERLAKU DI INDONESIA
}

\author{
Kadi Sukarna dan Jevri Kurniawan Hambali \\ Pasca Sarjana magister Ilmu Hukum Universitas Semarang
}

\begin{abstract}
ABSTRAK
Hukum waris adalah salah satu bagian dari hukum perdata secara keseluruhan dan merupakan bagian terkecil dari hukum kekeluargaan. Permasalahan tentang kewarisan yang sampai saat ini masih menjadi perdebatan di kalangan praktisi maupun akademisi adalah berkaitan dengan pewarisan kepada anak kandung yang beragama non-Muslim atau murtad dari agama Islam. Di satu sisi jelas bahwa dalam Hukum Islam seorang pewaris Muslim tidak boleh mewarisi disebabkan oleh tiga halangan (hijab hirman bil washfi) ${ }^{l}$ yaitu karena beda agama (termasuk murtad), membunuh dan hamba sahaya. ${ }^{2}$ Sebagaimana dalam Instruksi Presiden Republik Indonesia Nomor 1 Tahun 1991 tanggal 10 Juni $1991^{3}$ yaitu Kompilasi Hukum Islam mengatur dalam Pasal 173 yang dimana pada intinya tidak mengatur agama sebagai penghalang untuk dapat mewarisi, namun dalam Pasal 171 huruf b dan c Kompilasi Hukum Islam menyatakan bahwa pewaris dan ahli waris harus dalam keadaan beragama Islam. Hal ini menunjukkan bahwa apabila salah satunya tidak beragama Islam maka mereka tidak bisa saling mewarisi. Dalam implementasinya, wasiat wajibah diambil dari tirkah bukan dari mauruts hingga tidak melanggar ketentuan nasikh-mansukh ayat wasiat oleh ayat waris dan demi kepentingan keadilan, kemanfaatan dan kepastian hukum. Landasan hukum pemberian harta kepada non Muslim khususnya anak kandung dijelaskan sama sekali dalam yurisprudensi Mahkamah Agung bahkan diadopsi dalam kasus serupa oleh Pengadilan Agama, tetapi alasan hukum dipengaruhi oleh kepentingan kemaslahatan, keadilan, kemanusiaan dan keyakinan hakim untuk memutuskan. Dan pertimbangan hukum pemberian waris terhadap anak kandung non muslim tidak bertentangan dengan nilai-nilai Islam.
\end{abstract}

Kata Kunci: Ahli Waris, Anak Kandung Non Muslim, Hukum Islam 


\title{
IMPLEMENTATION OF INHERITANCE RIGHT TO NON MUSLIM CHIL- DREN IN ISLAMIC LEGAL PERSPECTIVE APPLIED IN INDONESIA
}

\author{
Kadi Sukarna and Jevri Kurniawan Hambali \\ Magister of Law Science University of Semarang
}

\begin{abstract}
The law of inheritance is one part of the civil law as a whole and it is the smallest part of the family law. The question of inheritance which is still debated among practitioners and academics is related to the inheritance of a non-Muslim or apostate Islam. On the one hand, it is clear that in Islamic Law a Muslim heir may not inherit it caused by three obstacles (hijab hirman bil washfi). It is because of different religions (including apostasy), killing and servant (hamba sahaya). As in the Presidential Instruction of the Republic of Indonesia Number 1 of 1991 dated June 10, 1991 of the Compilation of Islamic Law regulates in Article 173 which in essence does not regulate religion as a barrier to inherit, but in Article 171 letter b and c Compilation of Islamic Law states that the heir and the heirs must be in an Islamic state. This indicates that if one of them is not Moslem, they cannot inherit each other. In the implementation, the mandatory shall be taken from tirkah not from mauruts until it does not violate the provisions of nasikhmansukh verse of wills by the verse of inheritance and for the interests of justice, benefit and legal certainty. The legal basis for giving property to non-Muslim children, especially biological children, is fully explained in the jurisprudence of the Supreme Court even adopted in similar cases by the Religious Courts. However, the legal grounds are influenced by the benefit, and justice, humanity and judge's conviction to decide. Further, legal considerations of inheritance of non Muslim children are not contrary to Islamic values.
\end{abstract}

Keywords: Heirs, Non-Muslim Children, Islamic Law

\section{PENDAHULUAN}

\section{Latar Belakang Masalah}

Agama Islam sebagai agama mayoritas yang dipeluk oleh penduduk Indonesia berasimilasi ke dalam ideologi bangsa Indonesia dan menjadi suatu hukum Islam sebagai salah satu sumber hukum pembentuk hukum di Indonesia secara normatif dan formal yuridis.

Hukum Islam merupakan hukum yang bersifat universal, karena pada dasarnya berasal dari esensi religiusitas ke-Islam-an yang universal. Dengan kata lain apapun nasionalitas yang melekat pa- 
da personal seseorang maka hukum Islam berlaku atas personal yang beragama Islam. Namun untuk mewujudkan suatu hukum Islam yang sifatnya nasional bagi bangsa Indonesia yang mayoritas beragama Muslim bukan berarti tanpa hambatan, karena pada dasarnya sifat pluralitas sangat kental di dalamnya. Pluralitas yang tumbuh dalam bangsa Indonesia disebabkan karena adanya berbagai suku, kebudayaan, adat istiadat, terlebih lagi agama. Sehingga Hukum Islam dalam pluralitas nasional dalam perkembangannya sudah pasti harus berintegrasi dengan kondisi nasional bangsa Indonesia.Hukum Islam sampai saat ini semakin kokoh walaupun dalam pluralitas seperti agama - agama yang ajarannya tumbuh dan berkembang selain Agama Islam.Tentu saja agama atau kepercayaan dalam masyarakat merupakan hal yang sangat sensitif dan perlu pemahaman serta penyesuaian yang tepat dengan Hukum Islam.Untuk itu, sekarang ini hukum Islam yang meliputi hukum perkawinan, kewarisan, wasiat, hibah, wakaf, infaq, shodaqoh, dan zakat terus mengalami perkembangan dari tingkat sederhana sampai kompleks.Secara faktual, perkembangan hukum Islam yang sangat dinamis justru tidak hanya berada di ranah hukum perkawinan saja, melainkan pada ranah Hukum Waris Islam.

Hukum waris adalah salah satu bagian dari hukum perdata secara kese- luruhan dan merupakan bagian terkecil dari hukum kekeluargaan. ${ }^{4}$ Selanjutnya, warisan adalah soal apa dan bagaimana pelbagai hak-hak dan kewajibankewajiban tentang kekayaan seseorang pada waktu ia meninggal akan beralih kepada keluarga yang masih hidup. ${ }^{5}$ Sehingga hukum kewarisan dalam Islam mendapat perhatian yang besar karena dalam upaya pembagian warisan seringmenimbulkanakibat-akibatyang tidakmenguntungkanbagi keluarga yang ditinggalkan.

Padahal harta benda yang diberikan oleh Allah kepada umat manusia, di samping berfungsi untuk memenuhi kebutuhan pemiliknya dalam upaya mengabdi kepada yang Maha Pemberi, juga antara lain untuk mempererat hubungan persaudaraan. Namun kematian seseorang sering berakibat timbulnya silang sengketa dikalangan ahli waris mengenai harta peninggalannya.Hal seperti ini sangat mungkin terjadi, bilamana pihak-pihak terkait tidak konsisten dengan rambu-rambu yang telah ditetapkan. ${ }^{6}$

Permasalahan tentang kewarisan

\footnotetext{
${ }^{4}$ Eman Suparman, Hukum Waris Indonesia ${ }^{\circ}$ Dalam Perspektif Islam, Adat dan BW', Bandung:Refika Aditama, 2005, Cet ke-1, hal, 1.

${ }^{5}$ Ahmad Rofiq, Hukum Islam di Indonesia, Cet. III (Jakarta: Raja Grafindo Persada, 1998), hal 356.

${ }^{6}$ Satria Effendi M. Zain, Problematika Hukum Keluarga Islam Kontemporer, Ed 1, Cet. 1 (Jakarta: Kencana, 2008), hal. 233.
} 
yang sampai saat ini masih menjadi perdebatan di kalangan praktisi maupun akademisi adalah berkaitan dengan pewarisan kepada anak kandung yang beragama nonMuslim atau murtad dari agama Islam.Sebagaimana dalam Instruksi Presiden Republik Indonesia Nomor 1 Tahun 1991 tanggal 10 Juni $1991^{7}$ yaitu Kompilasi Hukum Islam mengatur dalam Pasal 173 yang dimana pada intinya tidak mengatur agama sebagai penghalang untuk dapat mewarisi, namun dalam Pasal 171 huruf $b$ dan c Kompilasi Hukum Islam menyatakan bahwa pewaris dan ahli waris harus dalam keadaan beragama Islam. Hal ini menunjukkan bahwa apabila salah satunya tidak beragama Islam maka mereka tidak bisa saling mewarisi. ${ }^{8}$ Berbeda dengan pembaharuan melalui suatu terobosan yang dilakukan oleh Mahkamah Agung pada tingkat kasasi dalam perkara kewarisan Nomor: 368.K1AG/1995, kemudian diikuti sebagai yurisprudensi pada Kasasi Mahkamah Agung Nomor: 51.KlAG/1999, Penetapan Pengadilan Agama Surabaya Nomor: 140/Pdt.P/2012/PA.SBY, dan Putusan Pengadilan Agama Kabanjahe No-

7Muchtar Syafari, Pertimbangan Hukum Syara' Tentang Kompilasi Hukum Islam, dalam buku tentang "Berbagai Pandangan Terhadap Kompilasi Hukum Islam", (Jakarta Yayasal Al-Hikmah, 1993/1994), hal. 23

${ }^{8}$ Ahmad Ali MD, Argumen Wasiyat Wajibah Bagi Ahli Waris Non Muslim Sebagai Salah Satu Alternatif Mendapatkan Hak Waris, Jurnal Mimbar Hukum dan Peradilan, (Jakarta: PPHIM, 2013), Edisi Nomor 77, hal. 61. mor: 2/Pdt.G/2011/PA.KBJ, Putusan Pengadilan Agama Medan Nomor : 1453IPdt.G/2013/PA.Mdn dan Putusan Pengadilan Jember Nomor: 204/Pdt.G/2007/PA.Jr, yang dimana pada dasarnya justru memberikan bagian harta pewaris kepada anak kandungnya yang beragama non-Muslim atau murtad dari Agama Islam melalui wasiat wajibah. Hal ini tentu saja menjadi sangat kontradiktif manakala asas-asas aturan hukum kewarisan yang sudah tertulis dalam Hukum Islam justru oleh lembaga peradilan kita diterobos dengan alasan kemaslahatan dan keadilan bagi masyarakat.

\section{TINJAUAN PUSTAKA}

Secara terminologis, hukum kewarisan Islam adalah hukum yang mengatur tentang pemindahan hak kepemilikan harta peninggalan/tirkah pewaris, menentukan siapa-siapa yang berhak menjadi ahli waris dan berapa bagian masing-masing. ${ }^{9}$ Definisi lain juga disampaikan oleh Muhammad Amin Suma ${ }^{10}$ yang dimana menurut pendapatnya hukum kewarisan Islam yaitu hukum yang mengatur peralihan pemilikan harta peninggalan (tirkah) pewaris, menetapkan siapasiapa yang berhak menjadi ahli waris, menentukan berapa

\footnotetext{
${ }^{9}$ Mardani, Hukum Kewarisan Islam di Indonesia, (Jakarta: Rajawali Pers, 2014), hal.1-2.

${ }^{10}$ Muhammad Amin Suma, Hukum Keluarga Islam di Dunia !slam, (Jakarta: Raja Grafindo Persada, 2004), hal. 108
} 
bagian masing-masing ahli waris, dan mengatur kapan pembagian harta kekayaan pewaris dilaksanakan.

\section{Menurut Mardani ${ }^{11}$ ilmu faraidh} atau ilmu waris adalah ilmu yang mengatur peralihan harta orang yang telah meninggal kepada orang yang masih hidup berdasarkan ketentuan syari'at Islam yakni AI-Qur'an, Sunnah, Ijma' Ulama, dan ljtihad Ulama. Sedangkan menurut M. ldris Ramulyo, ${ }^{12}$ hukum waris atau wirasah adalah hukum yang mengatur segala masalah yang berhubungan dengan pewaris, ahli waris, harta peninggalan, serta pembagian yang lazim disebut dengan hukum faraidh.

Faraidh merupakan bentuk jamak dari kata tunggal "faridhah" yang berarti bagian tertentu, sedangkan faraidh dapat diartikan bagian-bagian tertentu (yang diperuntukkan bagi ahli waris tertentu dalam hal atau keadaan tertentu). ${ }^{13}$ Selain itu, menurut Sayyid Sabiq kata faridha yang diambil dari kata fardh yang berarti taqdir juga dapat diartikan sebagal ketetapan atau ketentuan. ${ }^{14}$

Turunnya ayat-ayat AI-Qur'an yang mengatur pembagian warisan yang penunjukannya bersifat pasti (qath'iy al-

\footnotetext{
${ }^{11}$ Mardani, Op.Cit., hal. 3.

${ }^{12}$ M. Idris Ramulyo, Beberapa Masalah tentang Hukum Acara Perdata Peradilan Agama, (Jakarta: In Hill Co. 1991), hal. 42

${ }^{13}$ Ahmad Zahari, Op. Cit., hal. 22.

${ }^{14}$ Sayyid Sabiq, Fiqh Sunnah, (Jakarta: Pena Pundi Aksara, 2006), hal. 479.
}

dalalah) yang dimana merupakan refleksi sejarah dari adanya kecenderungan materialistis umat manusia, di samping sebagai rekayasa sosial terhadap sistem hukum yang berlaku pada masyarakat Arab pra-Islam pada masa itu. ${ }^{15}$

\section{Kerangka Teoritik}

Kerangka teori merupakan kerangka pemikiran atau butir-butir pendapat, teori, tesis mengenai suatu kasus atau permasalahan (problem) yang menjadi bahan perbandingan, pegangan teoritis yang mungkin disetujui atau tidak disetujui. ${ }^{16}$ Oleh karena itu, untuk menjelaskan rumusan masalah di atas, penulis memilih kerangka teori yang meliputi teori berlakunya Hukum Islam di Indonesia dan teori berkenaan dengan permasalahan di atas yaitu:

\section{a. Ajaran Tiga Nilai Dasar Hukum}

Gustav Radbruch ${ }^{17}$ mengajarkan bahwa hukum harus memuat tiga nilai dasar yaitu: Nilai Keadilan (Aspek Filosofis) yakni merupakan salah satu tujuan dari hukum selain dari kepastian hukum itu sendiri dan juga kemanfaatan hukum kead-

\footnotetext{
15 Ahmad Rofiq, Hukum Perdata Islam di Indonesia Edisi Revisi, (Jakarta: Rajagrafindo Persada, 2011), hal. 282.

${ }^{16}$ M. Solly Lubis, Filsafat llmu dan Penelitian, (8andung: Mandar Maju, 2004), hal. 27 dan 80.

${ }^{17}$ Adji Samekto, Pergeseran Pemikiran Hukum dari Era Yunani Menuju Postmodernisme, (Jakarta: Konstitusi Press, 2015), Cet. Ke-1, hal. 77-78.
} 
ilan itu terkait dengan pendistribusian yang merata antara hak dan kewajiban. Demikian sentral dan dominan kedudukan dan peranan dari nilai keadilan bagi hukum, Nilai Kepastian (Aspek Yuridis) yakni pertanyaan yang hanya bisa dijawab secara normatif, bukan sosiologis.Kepastian hukum secara normatif adalah ketika suatu peraturan dibuat dan diundangkan secara pasti karena mengatur secara jelas dan logis. Jelas dalam artian tidak menimbulkan keragu-raguan (multitafsir) dan logis dalam artian ia menjadi suatu sistem norma dengan norma lain sehingga tidak berbenturan atau menimbulkan konflik norma, Nilai Kemanfaa$\tan$ (Aspek Sosiologis) yakni hanyalah untuk menciptakan kemanfaatan atau kebahagiaan masyarakat. Gustav Radbuch menghubungkan antara bidang fakta dan bidang seharusnya, penggabungan keduanya dilandasi pada pemikiran bahwa sesungguhnya dalam kehidupan terdapat unsur fakta (das sein) dan unsur seharusnya (das sollen).Jadi keduanya hanya mampu dihubungkan oleh sebuah unsur yaitu budaya (culture).

b. Teori Kredo

Makna kredo identik dengan kata syahadah, yang bermakna persaksian.Menurut teori kredo, ${ }^{18}$ seseorang yang

${ }^{18}$ Juhaya S. Praja, Teori - Teori Hukum 'Suatu Telaah Perbandingan dengan Pendekatan Fil- menganut suatu keyakinan atau agama diharuskan tunduk dan patuh kepada hukum agama yang dianutnya.Landasan filosofis lahirnya teori kredo adalah kesaksian seseorang menjadi Muslim dengan mengucapkan dua kalimat syahadat sebagai konsekuensi logis dari pengucapan kredonya.

\section{c. Teori Receptio in Complexu}

Menurut Lodewijk Willem Christian van den Berg ${ }^{19}$ bahwa hukum yang berlaku bagi suatu masyarakat adalah hukum dari agama yang dianutnya.Atau secara ringkas dan sederhana disebut bahwa setiap orang beragama tunduk kepada hukum dari agama yang dianutnya. Sehingga, bagi orang Islam berlaku penuh hukum Islam, sebab ia telah memeluk agama Islam walaupun dalam pelaksanaannya terdapat penyimpanganpenyimpangan.

\section{d. Teori Receptie}

Christian Snouck Hurgronje ${ }^{20}$ menyebutkan bahwa bagi rakyat pribumi pada dasarnya berlaku hukum adat, dan hukum Islam akan berlaku apabila normanorma hukum Islam telah diterima dan diserap oleh masyarakat hukum adat.

e. Teori Receptie Exit

safat", (Bandung: UIN Sunan Gunung Djati, 2009), hal. 107.

${ }^{19}$ Aqib Suminto, Politik Islam Hindia Belanda, (Jakarta: LP3ES, 1985), hal. 9.

${ }^{20}$ H. Habiburrahman, Rekonstruksi Hukum Kewarisan Islam di Indonesia, (Jakarta: Kencana, 2011) Ed. Ke-1, Cet. Ke-1, hal 29. 
Hazairin $^{21}$ menurutnya hukum Islam adalah hukum yang mandiri dan lepas dari pengaruh hukum lainnya, sebagaimana ia menghubungkannya dengan sumber dan metode hukum Islam.

\section{f. Teori Receptio a Contrario}

Menurut Sajuti Thalib ${ }^{22}$ bahwa masalah waris bagi orang Islam berlaku hukum Islam, hukum Islam berlaku sesuai dengan cita-cita hukum, cita-cita moral dan batin umat Islam, kemudian hukum adat berlaku jika tidak bertentangan dengan ajaran Islam.

\section{METODE PENELITIAN}

Metode adalah proses, prinsipprinsip, dan tata cara memecahkan suatu masalah. Penelitian merupakan suatu sarana pokok dalam pengembangan iimu pengetahuan dan teknologi yang bertujuan untuk mengungkapkan kebenaran secara sistematis, metodologis dan konsisten melalui proses penelitian tersebut diadakan analisa dan konstruksi terhadap data yang telah dikumpulkan dan diolah. ${ }^{23}$ Adapun penelitian atau research adalah usaha untuk menemukan, mengembangkan dan menguji kebenaran, suatu pengetahuan, usaha mana dilakukan dengan metode-

\footnotetext{
${ }^{21}$ Loc. Cit.

${ }^{22}$ Ichtiyanto, Pengembangan Teor Berlakunya Hukum Islam di Indonesia, (Bandung: Rosdakarya, 1991), hal. 131-133.

${ }^{23}$ Soerjono Soekanto dan Sri Mamuji, Penelitian Hukum Normatif Suatu Tinjauan Singkat, (Jakarta: Rajawali Press, 2012), Cet. Ke-14, hal. 1.
}

metode ilmiah. ${ }^{24}$ Adapun metode penelitian yang digunakan yaitu:

\section{Metode Pendekatan}

Penelitian ini menggunakan metode pendekatan yuridis normatif, yaitu suatu penelitian hukum yang dilakukan dengan cara meneliti dan menelaah fakta yang ada sejalan dengan pengamatan di lapangan, kemudian dikaji berdasarkan peraturan perundang-undang yang terkait dengan acuan untuk memecahkan masalah. ${ }^{25}$ Pendekatan empiris dilakukan dengan cara meneliti di lapangan dengan menggunakan data primer. $^{26}$ Penyelenggaraan pendekatan empiris dilakukan guna memperoleh keterangan tentang hal-hal yang berkenaan dengan berbagai faktor pendorong pelaksanaan suatu peraturan yang berkaitan dengan permasalahan yang akan diteliti.

Pendekatan yuridis normatif ini dimaksudkan untuk melakukan upaya penjelasan atas permasalahan yang akan diteliti dengan hasil penelitian yang diperoleh dalam hubungan dengan aspek hukum dan realita yang terjadi melalui Implementasi Hak Atas Ahli Waris Anak Kandung Non Muslim Dalam Perspektif Hukum Islam yang Berlaku di Indonesia.

\section{Spesifikasi Penelitian}

Penelitian ini dikategorikan sebagai

\footnotetext{
${ }^{24}$ Sutrisno Hadi, Metodologi Research, (Yogyakarta: Abdi Offset, 2000), Jilid ke-1, hal. 4.

${ }^{25} \mathrm{lbid}$, hal. 13

${ }^{26}$ Soerjono Soekanto dan Sri Mamuji,Op.Cit., hal.1
} 
penelitian yang bersifat deskriptif analitis.Deskriptif maksudnya adalah penelitian yang bertujuan untuk melukiskan keadaan obyek atau peristiwanya tanpa wawancara mendalam. ${ }^{27}$ Sedangkan analitis didefinisikan sebagai upaya kegiatan analisa data secara komprehensif, dengan kata lain penelitian kualitatif jauh lebih subyektif daripada penelitian kuantitatif dan menggunakan metode yang berbeda dari mulai pengumpulan informasi, terutama individu, dalam menggunakan wawancara secara mendalam.

\section{Sumber dan Jenis Data}

Data Sekunder

Data sekunder atau data kepustakaan yakni data yang berasal dari dokumen - dokumen resmi, buku - buku, hasil penelitian yang berwujud laporan, buku harian dan seterusnya. ${ }^{28}$ Adapun data sekunder meliputi:
1) Bahan Hukum Primer adalah bahan hukum yang bersifat au- toritatif artinya mempunyai otoritas, yang terdiri dari pera- turan perundang - undangan dan peraturan pemerintah. ${ }^{29}$
2) Bahan Hukum Sekunder merupakan publikasi tentang hukum yang bukan merupakan

\footnotetext{
${ }^{27}$ Ibid, hal. 3

${ }^{28}$ Soerjono Soekanto, Op.Cit., him. 12

${ }^{29}$ Peter Mahmud Marzuki, Penelitian Hukum, (Jakarta: Kencana, 2009), hlm. 141
}

dokumen resmi. ${ }^{30}$ Bahan sekunder meliputi bahan seminar, jurnal, laporan penelitian, media surat kabar, internet, buku-buku yang berkaitan dengan permasalahan dalam tesis ini.

3) Bahan Hukum Tersier, yaitu berupa kamus, ensiklopedia dan artikel, serta beberapa bahan hukum tersier lainnya guna menjelaskan bahan hukum primer dan bahan hukum sekunder.

\section{TEKNIK ANALISIS DATA}

Karena metode yang digunakan oleh penulis dalam penelitian ini adalah metode deskriptif analitis, maka data-data yang diperoleh dari studi lapangan maupun studi pustaka akan dikumpulkan, kemudian data yang terkumpul dituangkan dalam bentuk uraian logis dan sistematis, selanjutnya dianalisis untuk memperoleh kejelasan penyelesaian dan pembenaran yang konkrit terhadap pengambilan suatu keputusan yang bemilai hukum, kemudian ditarik kesimpulan secara induktif. Metode induktif ${ }^{31}$ merupakan suatu cara penelitian yang berangkat dari fakta-fakta yang ditemukan di lapangan kemudian diana-

\footnotetext{
${ }^{30}$ Ibid, hlm. 143

31 Sudarwan Denim, Emanjadi Penliti Kualitatif, (bandung: Pustaka Setia, 2002)., hlm.62
} 
lisis dengan konsep dan teori yang digunakan dalam penelitian mengenai Implementasi Hak Atas Ahli Waris Anak Kandung Non Muslim Dalam Perspektif Hukum Islam yang Berlaku di Indonesia.

\section{PEMBAHASAN}

Wasiat wajibah pada dasarnya adalah pengembangan dari konsep wasiat pada umumnya.Menurut pendapat narasumber Muh. Nasikhin selaku Hakim Pengadilan Agama Giri Menang yang menyatakan bahwa wasiat wajibah hampir sama dengan wasiat pada umumnya, yang membedakan hanyalah subjektifitasnya saja, yang dimana si pewasiat tersebut tidak melakukan wasiat dan sudah meninggal dunia yang pelaksanaannya dilakukan sesudah meninggal dunia dan hakim yang menjatuhkan hukumnya untuk wajib dilaksanakan dengan konsep wasiat pada umumnya dengan melihat faktor-faktor yang sifatnya kasuistis.

Meskipun secara normatif wasiat wajibah tidak ditemukan dalam ketentuan Al-Qur'an, As-Sunnah serta hadisthadistshahih sebagai dasar legitimasinya. Namun justru wasiat wajibah ditemukan di Mesir sebagai negara pertama yang mencetuskan konsep lembaga wasiat wajibah ke dalam Undang-Undang Wasiat Mesir "Qanunul Wasiat" yang memberikan harta pewaris kepada ahli waris pengganti seperti cucu. Kemudian oleh Indonesia diadopsi dan diakomodir ke dalam Pasal 185 Kompilasi Hukum Islam yakni:

a. Ahli waris yang meninggal lebih dahulu dari pada si pewaris maka kedudukannya dapat digantikan oleh anaknya, kecuali mereka yang tersebut dalam Pasal 173.

b. Bagian ahli waris pengganti tidak boleh melebihi dari bagian ahli waris yang sederajat dengan yang diganti.

Tetapi pada Pasal 185 Kompilasi Hukum Islam ini tidak menempatkan bagian ahli waris pengganti kedalam konteks wasiat wajibah sebagaimana Qanunul Wasiat Mesir dan Pasal 209 Kompilasi Hukum Islam, melainkan dipersepsikan seperti Plaatsvervulling dalam Pasal 841 Burgerlijk Wetboek namun tetap berbeda secara esensinya.

Merujuk kepada ketentuan dalam Kompilasi Hukum Islam, pemberian harta melalui wasiat wajibah dilakukan sematamata dengan pertimbangan demi kemanusiaan, rasa keadilan dan kemaslahatan menetapkan wajibnya berwasiat kepada Pewaris yang pada saat hidupnya tidak berwasiat, karena jika melihat konteks cucu disini akan sangat tidak adil ketika seorang anak ditinggal mati oleh ayahnya dan menjadi yatim 
tetapi terhalang dan tidak mendapatkan harta warisan dari pewaris karena AlQur'an dan hadist tidak mengenal ahli waris pengganti ataupun pengganti ahli waris. Sehingga menurut Hakim Pengadilan Agama Mataram H. Abdul Salam berpendapat bahwa jika memahami kondisi "cucu" yang hanya karena taqdir Allah semata orang tuanya yang semestinya mendapat warisan tetapi ia meninggal lebih dahulu dari pewaris (Nenek/ Kakek). Apalagi faktanya "cucu" tersebut sedang dalam keadaan yatim; bila tetap berpegangan dengan fiqih klasik (madzhab sunni), maka fiqih Islam untuk sekarang ini dirasakan seperti jauh dari rasa keadilan dan perikemanusiaan.

Perkembangan konsep wasiat wajibah dari tahun ke tahun mengalami perluasan penafsiran dan paradigma, untuk sekarang ini konsep wasiat wajibah tidak terkotak pada kepentingan cucu, anak angkat maupun orang tua angkat saja melainkan sudah melampaui secara lintas agama. Wasiat wajibah secara lintas agama dapat dipahami sebagai pemberian harta si mayit/ pewaris yang beragama Muslim kepada seorang non Muslim, yang menjadi persoalan adalah seorang non Muslim ini menerima harta warisan saja sudah menjadi banyak perdebatan terlebih lagi seorang yang non Muslim ini adalah anak kandung dari si mayit/ pewaris sendiri.
Dasar hukum pemberian harta kepada anak kandung non Muslim adalah hibah terdapat dalam Al-Qur'an surat AnNisa ayat 8 ditegaskan bahwa:

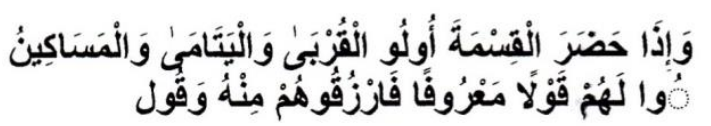

Artinya : Dan apabila sewaktu pembagian itu hadir kerabat, anak yatim dan orang miskin, maka berilah mereka dari harta itu (sekedarnya) dan ucapkanlah kepada mereka perkataan yang baik.

Jadi, kerabat dalam ayat ini bisa jadi adalah orang non Muslim termasuk anak kandung non Muslim, sehingga pemberian "sekedarnya" bukanlah konsep hukum wasiat tetapi konsep hibah, tetapi tetap atas kesepakatan ahli waris yang lain.

\section{KESIMPULAN}

Pemberian harta melalui wasiat wajibah sama halnya sepertiwasiat pada umumnya, dalam mekanismenya tidak diambil dari hartawaris (mauruts). Wasiat wajibah diambil dari harta peninggalan(tirkah) setelah dikurangi dengan kewajiban-kewajiban sepertihutang, nadzar, biaya-biaya yang timbul saat proses kematianpewaris dan sebagainya. Dengan kata lain harta peninggalan dikurangi kewajiban- 
kewajiban pewaris kemudian pada saat itulah wasiat wajibah dikeluarkan dan diberikan, dan setelah itu bisa dikatakan harta waris, kemudian dilakukan pembagian kepada ahli waris. Praktik pemberian harta kepada anak kandung non Muslim sampai saat ini masih banyak yang menentang, beberapa masih bisa menerima hal tersebut. Pada praktiknya di Pengadilan Agama sendiri dalam memberikan harta peninggalan kepada anak kandung non Muslim saat ini lebih banyak mempertimbangkan kepada aspekaspek yang bersifat keadilan, kemanfaatan barulah kepastian hukum. Sehingga implementasinya di pengadilan tidaklah mudah, karena harus melalui proses formil dan materiil terlebih dahulu yang dimana hakim harus melihat secara kasuistis dalam pemberian harta warisan melalui wasiat wajibah ini, apakah anak kandung non Muslim ini layak ataukah tidak. Kelayakan ini ditinjau dari fakta persidangan yangkemudian dipadukan dengan konstruksi keyakinan hakim yangsifatnya relatif dan abstrak, karena hakim dalam menilai kasus banyakaspek dipertimbangkan. Untuk keseluruhan kasus semacam ini tidakbisa digeneralisasikan hanya bersifat kasuistis.

Mahkamah Agung dalam putusan Kasasi Nomor 368 K/AG/1995 danputusan Nomor 51 K/AG/1999 dalam konstruksi pertimbangannyatidak mencantumkan argumen pembenaran pemberian wasiat wajibahkepada non Muslim. Hal ini berdampak kepada ketidakpastian hukumdan keadilan bagi pihak-pihak yang berperkara, karena tujuan hukum adalah memberikan keadilan bahkan yurisprudensi ini dijadikan bahan pertimbangan-pertimbangan hukum sesudahnya sebagai dasar untuk memutuskan perkara wasiat wajibah kepada non Muslim. Konstruksi pertimbangan hakim untuk saat ini lebih didasarkan kepada kepentingan keadilan, kemanfaatan barulah kepastian meskipun pada kenyataannya dalam pertimbangannya terlepas secara normatif mengenai hukum waris Islam, namun lebih menarik asas-asas hukum dan melakukan penafsiran terhadap surat Al-Baqarah ayat 180 da!am memberikan putusan yang seadiladilnya. Konstruksi pertimbangan hakim untuk membenarkan adanya wasiat wajibah kepada anak kandung non Muslim sejatinya lebih didasarkan kepada dorongan-dorongan tujuan hakim dalam sistem peradilan yang dimana hakim hanya menghendaki keadilan sebagai tujuan utama serta kemanfaatan. Selain itu, konstruksi pertimbanganhakim lebih dipengaruhi oleh keyakinan hakim untuk memutus perkaraserta menilai ataupun menentukan keadilan itu sendiri. Keberadaanasas egaliter juga menjadi salah satu tonggak konstruksipertimbangan 
hakim untuk memutus perkara pemberian harta kepadaanak kandung non Muslim melalui wasiat wajibah. Menurut konsepmaqashid al-syar'iah, Hukum kewarisan Islam terkait pemberian harta kepada anak kandung non Muslim tidak hanya bertentangan dengan hukum syari'at kewarisan Islam, tetapi juga bertentangan dengan tujuan syari'at itu sendiri yaitu memelihara jiwa (hifz an-nafs), dan memelihara akal (hifz an-nasl), bahkan bertentangan dengan memelihara agama (hifz ad-din). Namun secarapraktis, dengan menggunakan teori maqashid al-syar'iah bahwa pemberian wasiat wajibah kepada anak kandung non Muslim dapat dibenarkan, dan sejalan dengan prinsipprinsip Islam yang mendasar yakni prinsip kesetaraan (al-musawah), kemaslahatan (al-mashlahah), keadilan (al-adalah), persaudaraan (al-ukhuwah), kebebasan memeluk agama (al-hurriyah). Kemudian Mashlahah al-mursalah yaitu prinsip nilai kemaslahatan sebagai bahan pertimbangan hakim dalam memberikan harta kepada anak kandung non Muslim dengan melihat kemaslahatan atau kemanfaatan umum ditengah adanya pluralitas. Sehingga, jelas bahwa pertimbangan hakim untuk memberikan harta kepada anak kandung non Muslim melalui wasiat wajibah patut diperhatikan karena hal tersebut sematamata menginginkankeadilan di tengahtengah masyarakat plural. Keadilan adalah tombak utama tercapainya kesejahteraan khususnya dalam hukum waris Islam.

\section{DAFTAR PUSTAKA}

Adji Samekto, Pergeseran Pemikiran Hukum dari Era Yunani Menuju Postmodernisme, (Jakarta: Konstitusi Press, 2015), Cet. Ke-1

Ahmad Ali MD, Argumen Wasiyat Wajibah Bagi Ahli Waris Non Muslim Sebagai Salah Satu Alternatif Mendapatkan Hak War$i$, Jurnal Mimbar Hukum dan Peradilan, (Jakarta: PPHIM, 2013), Edisi Nomor 77

Ahmad Rofiq, Hukum Islam di Indonesia, Cet. III (Jakarta: Raja Grafindo Persada, 1998)

Hukum Perdata Islam di Indonesia Edisi Revisi, (Jakarta: Rajagrafindo Persada, 2011)

Aqib Suminto, Politik Islam Hindia Belanda, (Jakarta: LP3ES, 1985)

Eman Suparman, Hukum Waris Indonesia ${ }^{\circ}$ Dalam Perspektif Islam, Adat dan $B W^{\prime}$, Bandung:Refika Aditama, 2005, Cet ke-1

H. Habiburrahman, Rekonstruksi Hukum Kewarisan Islam di Indonesia, (Jakarta: Kencana, 2011) Ed. Ke1, Cet. Ke-1

Ichtiyanto, Pengembangan Teor Berlakunya Hukum Islam di Indonesia, (Bandung: Rosdakarya, 1991) 
Juhaya S. Praja, Teori - Teori Hukum 'Suatu Telaah Perbandingan dengan Pendekatan Filsafat", (Bandung: UIN Sunan Gunung Djati, 2009)

M. Idris Ramulyo, Beberapa Masalah tentang Hukum Acara Perdata Peradilan Agama, (Jakarta: In Hill Co. 1991)

M. Solly Lubis, Filsafat llmu dan Penelitian, (8andung: Mandar Maju, 2004)\

Mardani, Hukum Kewarisan Islam di Indonesia, (Jakarta: Rajawali Pers, 2014)

Muchtar Syafari, Pertimbangan Hukum Syara' Tentang Kompilasi Hukum Islam, dalam buku tentang "Berbagai Pandangan Terhadap Kompilasi Hukum Islam", (Jakarta Yayasal Al-Hikmah, 1993/1994)

Muhammad Amin Suma, Hukum Keluarga Islam di Dunia!slam, (Jakarta: Raja Grafindo Persada, 2004)

Peter Mahmud Marzuki, Penelitian Hukum, (Jakarta: Kencana, 2009)

Satria Effendi M. Zain, Problematika Hukum Keluarga Islam Kontemporer, Ed 1, Cet. 1 (Jakarta: Kencana, 2008)

Sayyid Sabiq, Fiqh Sunnah, (Jakarta: Pena Pundi Aksara, 2006)

Soerjono Soekanto dan Sri Mamuji, Penelitian Hukum Normatif Suatu Tinjauan Singkat, (Jakarta: Rajawali Press, 2012), Cet. Ke-14

Sudarwan Denim, Emanjadi Penliti Kualitatif, (bandung: Pustaka Setia, 2002)
Sutrisno Hadi, Metodologi Research, (Yogyakarta: Abdi Offset, 2000), Jilid ke-1 